\title{
COMMENTS
}

\section{Ex Parte Contacts and Institutional Roles: Lessons From the OMB Experience}

\author{
Richard A. Nagareda $\dagger$
}

The Administrative Procedure Act ("APA") defines ex parte contacts as "oral or written communication[s] not on the public record with respect to which reasonable prior notice to all parties is not given." Widespread agreement exists regarding the appropriate treatment of these contacts outside of informal rulemaking. In formal rulemaking or adjudication, the APA expressly prohibits all ex parte contacts between interested parties and government regulatory agencies. ${ }^{2}$ As a supplemental protection, the APA stipulates that any ex parte contacts received in violation of this prohibition must be summarized and placed in the public record. ${ }^{3}$ The APA's constraints thus encompass all situations in which an administrative agency seeks to exercise power based on information and policy arguments obtained through trial-type procedures. ${ }^{4}$ The justification for these requirements lies in the APA's understanding of formal procedures as following a judicial model of decision making. Since one cannot seek to sway a court through off-therecord communications, so too interested parties cannot use similar means in formal administrative proceedings.

This categorical argument, however, does not offer an answer in the vast majority of rulemaking scenarios that follow informal procedures. Where an agency formulates policy not through rigid trial-type mechanisms but instead through more streamlined pro-

$\dagger$ A.B. 1985, Stanford University; J.D. Candidate 1988, The University of Chicago.

15 U.S.C. $\$ 551(14)$ (1982). The APA definition goes on to exclude "requests for status reports."

25 U.S.C. $\$ 557(\mathrm{~d})(1)(\mathrm{A})$.

35 U.S.C. \& 557(d)(1)(C).

+ See 5 U.S.C. § 556. 
cedures on the legislative model, ${ }^{5}$ the APA offers no direct guidance for the treatment of ex parte contacts. This statutory gap has proven problematic in recent years where off-the-record communications-often containing critical data or policy arguments from regulated industry-have threatened to distort decision making within administrative agencies. ${ }^{6}$

Section I begins with an outline of the policy issues presented in this area followed by a summary of early judicial efforts to control ex parte contacts. It then outlines several developments that place ex parte contacts in a new light. Specifically, Section I addresses the problems and opportunities raised by (1) the Reagan Administration's Executive Orders 12,291 and 12,498, which specify a supervisory role for the Office of Management and Budget ("OMB") in the regulatory process, and (2) the political pressures leading, in 1986, to a broadening of OMB disclosure requirements for ex parte contacts.

Section II addresses the implications of the new OMB rules for the ideals underlying judicial review, the potential sources of judicial authority to govern ex parte contacts, and the problems involved in a judicial solution to the ex parte contacts issue. Section III examines the conditions under which Congressional oversight can secure the values served by judicial review while avoiding many of the institutional problems of court-generated standards. Finally, Section IV uses the OMB experience as a basis for drawing general conclusions concerning the proper roles of Congress, the President, and the courts in the regulatory process.

\section{BACKGROUND}

\section{A. Policy Issues}

Before delving into the current case law on ex parte contacts,

S See Stephen G. Breyer and Richard B. Stewart, Administrative Law and Regulatory Policy 563 (2d ed. 1985)("Breyer and Stewart Casebook").

- For early literature on ex parte contacts, see, e.g., Paul R. Verkuil, Jawboning Administrative Agencies: Ex Parte Contacts by the White House, 80 Colum.L.Rev. 943 (1980); Glenn T. Carberry, Ex Parte Communications in Off-the-Record Administrative Proceedings: A Proposed Limitation on Judicial Innovation, 1980 Duke L.J. 65; Nathaniel Stone Preston, A Right of Rebuttal in Informal Rulemaking: May Courts Impose Procedures to Ensure Rebuttal of Ex Parte Communications and Information Derived from Agency Files After Vermont Yankee?, 32 Ad.L.Rev. 621 (1980); Note, Ex Parte Communication During Informal Rulemaking, 14 Colum.J.L. \& Soc.Prob. 269 (1979); Note, Due Process and Ex Parte Contacts in Informal Rulemaking, 89 Yale L.J. 194 (1979); Ernest Gellhorn and Glen O. Robinson, Rulemaking "Due Process": An Inconclusive Dialogue, 48 U.Chi.L.Rev. 201 (1981). 
one should understand the broader policy issues that these communications raise. In informal rulemaking, administrative agencies typically articulate and implement public policy pursuant to broad grants of authority from Congress. The problems raised by legislative delegations lie at the core of the policy debate surrounding ex parte contacts.

To a large extent, delegation accounts for the character of the agency decision making process. Given the limited amount of time that Congress as an institution can devote to any particular area of public policy, Congress relies on agencies-as repositories of technical expertise-to flush out the details of the regulatory framework after exhaustive investigation and analysis. The limitations of Congress also come into play where reliance on expertise alone will not dictate agency decisions. In complex areas, the most sophisticated technical studies still may leave substantial indeterminacy. The agency therefore must act by reference to a set of subjective policy presumptions: for example, "when in doubt, impose the most stringent feasible standard for exposure to harmful substances." Delegation is especially problematic where it evinces a Congressional unwillingness or inability to resolve heated disputes over the content of these presumptions. ${ }^{8}$ Where statutes offer no specific guidance, the agency itself must ascertain and reconcile the competing interests involved. ${ }^{\circ}$ This aspect of delegation raises two strong policy arguments in favor of ex parte communications:

1. In contentious regulatory disputes, off-the-record discussions with the agency can provide a means for interested parties to

7 In essence, this describes the efforts of the Occupational Safety and Health Administration ("OSHA") to tighten its exposure standard for the carcinogenic chemical benzene. See Industrial Union Dept. v. American Petrol. Inst., 448 U.S. 607 (1980).

- For discussion of these problems, see id. at 685-88 (Rehnquist concurring).

- In upholding Environmental Protection Agency ("EPA") measures to reconcile air pollution control with industrial expansion, the Supreme Court noted:

[T] he [EPA] Administrator's interpretation represents a reasonable accommodation of manifestly competing interests and is entitled to deference: the regulatory scheme is technical and complex, the agency considered the matter in a detailed and reasoned fashion, and the decision involves reconciling conflicting policies. Congress intended to accommodate both interests, but did not do so itself on the level of specificity presented by these cases. Perhaps that body consciously desired the Administrator to strike the balance at this level, thinking that those with great expertise and charged with responsibility for administering the provision would be in a better position to do so; perhaps it simply did not consider the question at this level; and perhaps Congress was unable to forge a coalition on either side of the question, and those on each side decided to take their chances with the scheme devised by the agency. For judicial purposes, it matters not which of these things occurred.

Chevron U.S.A. v. Natural Res. Def. Council, 467 U.S. 837, 865 (1984)(footnotes omitted). For further discussion of Cheuron, see note 127. 
convey policy preferences-especially, a willingness to accept particular levels of regulation-that they might hesitate to reveal in public for fear of losing bargaining leverage vis-à-vis opposition groups. Under such conditions, ex parte contacts which convey the parties' true negotiating positions support the underlying rationale for legislative delegations: namely, the expeditious accomplishment of public policy by administrative bodies. An agency with access to the "bottom line" of all concerned groups thereby may fashion rules within its delegated authority to minimize the possibility that litigation after the fact will impede the effectuation of federal policy. ${ }^{10}$ Indeed, when delegation is symptomatic of Congress' desire to transfer contentious debate over policy details to the agency setting, such political negotiations are consistent with legislative will.

2. The flow of discussion may proceed in the opposite direction as well. An agency may wish to push industry toward alternative systems, such as self-regulation, that accomplish regulatory goals while reducing the need for costly federal administration. The ability to talk off-the-record can enhance the leverage of the agency in such negotiations, since the agency thereby can offer industry the opportunity to relent without suffering public defeat.11

While ex parte contacts can greatly enhance the ability of agencies to effectuate policy, such communications also carry significant risks due to the ambiguous position of administrative agencies in the scheme of government institutions. ${ }^{12}$ Though entrusted with broad delegations of authority over matters of considerable political sensitivity, agencies are not subject to the normal

${ }^{10}$ A simple example illustrates this point. Take a case in which the EPA must establish standards for a carcinogenic chemical under a vague statutory delegation to weigh public health against the economic burdens on regulatees. Technical analyses of health risks are largely indeterminate for the low exposure levels in question. In their public presentations during the notice and comment period, industry argues for a 50 parts per million ("ppm") exposure standard while environmentalists call for a $20 \mathrm{ppm}$ rule. The two groups select their respective public positions in order to enhance their negotiating power vis-à-vis opponents. In fact, industry would be satisfied with a $30 \mathrm{ppm}$ standard while environmentalists would decline to challenge any standard below $40 \mathrm{ppm}$. Nonetheless, both groups would feel hesitant to reveal these preferences in public. Industry understandably would fear that such revelations might lead to a $30 \mathrm{ppm}$ standard, their minimum acceptable outcome. A corresponding fear would prevent environmentalists from revealing their true preferences. If EPA could obtain this important information off-the-record, it could fashion a rule-for example, a $35 \mathrm{ppm}$ standard-that would implement its statutory mandate without the burdensome delays of litigation. Of course, litigation would be unavoidable in cases where no overlap existed between the true positions of the parties.

${ }^{11}$ For more detailed exposition of both points, see Section I.B's treatment of Action for Children's Television v. F.C.C., 564 F.2d 458 (D.C.Cir. 1977).

12 See Breyer and Stewart Casebook at 41-44 (cited in note 5). 
electoral safeguards of Congress itself. As a consequence, one may not simply analogize ex parte contacts to the back door lobbying efforts characteristic of the legislative process. Secret communications with agencies insulated from electoral pressures raise the potential for wide deviations from delegated authority. Indeed, offthe-record contacts fit neatly within familiar notions of agency "capture." These fears ultimately rest on a concern for the rule of law: namely, that agency decision making should take place in a manner that ensures fidelity to substantive Congressional legislation.

In an administrative context, the term "rule of law" takes on a meaning different from its more common usage in relation to judicial decisions. Within the boundaries of its delegated authority, an agency-at least when operating through rulemaking proceedings ${ }^{13}$-need not establish rules that are principled in the way that decisions of a court must be principled. ${ }^{14}$ If the underlying statute sets forth two permissible concerns such as economic growth and pollution control, an agency may say, in one area, that economic growth should take priority while maintaining, in another instance, that pollution control should take priority. Where statutory directives and technical data are inconclusive, an agency legitimately may set policy based on a prudential evaluation of the risk of political outcry from concerned groups-outcry that can significantly delay the effectuation of federal policy. ${ }^{18}$ The key constraint of the rule of law, in an administrative context, holds that in no instance may an agency reach a decision by considering legally impermissible factors or, more generally, by skewing its analysis toward a particular substantive outcome. ${ }^{16}$

An appropriate solution to the ex parte contacts problem must reconcile rule of law values with competing concerns for agency expertise and political responsiveness. To ascertain the proper degree of restraint to place on agencies in this regard, one should remain

1s Constraints exist to assure consistency of administrative decisions in adjudication. See Arizona Grocery v. Atchison Ry., 284 U.S. 370 (1932) (agencies are bound by their own rules in individual adjudications, until such rules are properly changed through rulemaking proceedings).

14 On the importance of principle in judicial decision making, see Alexander M. Bickel, The Least Dangerous Branch 23-28 (2d ed. 1986).

${ }^{15}$ By contrast, the "all deliberate speed" remedy in the Supreme Court's landmark desegregation decision - arguably based on considerations of political acceptability-has engendered "widespread criticism." See Geoffrey R. Stone, Louis M. Seidman, Cass R. Sunstein, and Mark V. Tushnet, Constitutional Law $468-70$ (1986) (summarizing criticisms of the remedy in Brown v. Board of Education, 349 U.S. 294 (1955)).

18 For more detailed discussion of these constraints, see Sections II.A.1-2. 
mindful of the institutional context in which agencies must function. Legislative delegations not only shape the tasks to be performed by the agency, they also reflect broader principles underlying the Constitution's separation of powers.

Specifically, these principles contain both positive and negative implications for exercise of government power. First, the separation of powers creates a division of labor for the pursuit of public policy objectives. For example, administrative agencies possess unique institutional tools for data collection and analysis regarding different policy options; the President, as head of the executive branch, stands in a position to coordinate policy making by different agencies; courts possess special abilities to articulate and enforce the rule of law through statutory and constitutional interpretation. This positive component of the separation of powers helps government meet the regulatory needs of modern society while imposing the constraints of law. A regime of safeguards for ex parte contacts should remain sensitive to this underlying rationale for administrative agencies in a system of separated powers: namely, the expedient implementation of substantive federal policy.

Second, the division of labor among institutions has a negative, limiting aspect as well. The separation of federal authority creates intense institutional jealousies that can constrain the exercise of power. ${ }^{17}$ While the President stands at the apex of the federal bureaucracy, Congressional oversight committees compete with him for power over agency policy. Madisonian checks and balances thereby raise the possibility of a system to police ex parte contacts that links enforcement of limitations on agencies to the political engine of institutional turf battles. The Congressional backlash engendered by OMB contacts with regulated industry-outlined in Section III-represents an important step along these lines.

B. The Parameters of Current Law: The D.C. Circuit and the APA

The primary source of case authority regarding ex parte contacts consists of decisions by the United States Court of Appeals for the District of Columbia Circuit. In 1959, the D.C. Circuit in Sangamon Valley Television Corp. $v$. United States held undisclosed ex parte contacts permissible in informal rulemaking as long as the proceeding does not involve "resolution of conflicting pri-

${ }^{17}$ See Federalist 51. 
vate claims to a valuable privilege."18 The D.C. Circuit thus opened the door to ex parte contacts in all informal rulemakings apart from those that resembled traditional adjudication. ${ }^{10}$

The regime established by Sangamon Valley reflected a bipolar conception of administrative behavior under which courts categorized particular agency functions either as judicial decisions (by analogy to adjudication by courts) or as legislative decisions (similar to the process used by Congress). ${ }^{20}$ The law barred ex parte contacts in all proceedings under the judicial rubric-formal rulemaking and formal adjudication (pursuant to express APA provisions), as well as informal rulemaking resembling adjudication (pursuant to Sangamon Valley)_but permitted contacts in all other informal rulemaking proceedings by analogy to legislative decisions.

Sangamon Valley held sway until 1977 when the D.C. Circuit decided Home Box Office, Inc. ("HBO") v. FCC. ${ }^{21}$ There, the FCC Commissioner had engaged in undisclosed private meetings with industry representatives after the public record had been closed concerning FCC regulation of cable television programs. ${ }^{22}$ To govern such contacts, $H B O$ imposed "three distinct requirements: (1) a flat prohibition on agency receipt of views and information outside the usual channels for public comment; (2) a requirement that such views and information, if received, be memorialized and placed in the administrative file for public comment; and (3) a duty to place such views and information in the record for judicial review."23

$H B O$ 's flat ban on ex parte contacts has received severe criti-

18269 F.2d 221, 224 (D.C.Cir. 1959).

19 See Breyer and Stewart Casebook at 641 (cited in note 5).

${ }^{20}$ See Ronald A. Cass, Models of Administrative Action, 72 Va.L.Rev. 363, 367, 376-77 (1986).

${ }^{21} 567$ F.2d 9 (D.C.Cir. 1977).

${ }^{22}$ Documents filed with the court did not allow "an assessment of what was said to the Commission by the various persons who engaged in ex parte contacts." Id. at 52.

${ }^{2 s}$ Memorandum from Theodore B. Olson, Assistant Attorney General, Department of Justice, Office of Legal Counsel, to David Stockman, Director, Office of Management and Budget (April 24, 1981), in Regulatory Reform Legislation of 1981, Hearings on S. 344 and S. 1080 before the Senate Committee on Governmental Affairs, 97th Cong., 1st Sess. 88, 90 (1981). See 567 F.2d at 55-57.

$H B O$ grounded these requirements on three sources of law: (1) the Supreme Court's requirement in Citizens to Preserve Overton Park v. Volpe, 401 U.S. 402 (1971), of review on "the full administrative record," rooted in APA $\S 706$ 's power of judicial review; (2) notions of fairness implicit in constitutional due process; and (3) APA provisions for adversarial discussion in informal rulemaking. Id. at 54-56. For analysis of the potential sources of judicial authority in this area, see Section II.B. 
cism. As a doctrinal matter, this aspect of $H B O-a$ purely procedural requirement lacking support in the text or history of the APA-may not survive the Supreme Court's subsequent invalidation of similar judicially imposed procedures in Vermont Yankee Nuclear Power Corp. v. NRDC. ${ }^{24}$ There, the Nuclear Regulatory Commission ("NRC") had engaged in informal rulemaking proceedings to identify the health risks associated with the disposal of spent fuel from a "typical" nuclear power plant. The NRC subsequently used these general conclusions in an individual licensing proceeding involving the Vermont Yankee plant. ${ }^{25}$ The D.C. Circuit found the underlying rulemaking proceeding invalid where the NRC had complied with APA procedures but had failed to permit adequate adversarial discussion of the waste disposal issue. ${ }^{26}$ The Supreme Court reversed, holding the APA to preclude, absent exceptional circumstances, judicially imposed procedures for informal rulemaking beyond those in APA $\S 553$ or other relevant statutes. Though subsequent Supreme Court decisions shed new light on this reasoning-a matter considered in Section II.A.3-Vermont Yankee continues to cast doubt on the legal basis for $H B O$ 's ban. Moreover, as a policy matter, a flat ban remains insensitive to the significance of ex parte contacts for agency expertise and political responsiveness.

Shortly after $H B O$, a different D.C. Circuit panel in Action for Children's Television ("ACT") v. F.C.C. declined to apply HIBO's ban retrospectively. ${ }^{27} A C T$ merits close examination both for its facts and its doctrinal analysis. The case involved a demand by a private political organization, ACT, for the FCC to ban all commercials on children's television shows. ${ }^{28}$ The subject proved highly contentious due to the television industry's need for commercial revenues to pay for children's programming.

After expressions of "widespread public support for ACT's

24435 U.S. 519 (1978). See Carberry, 1980 Duke L.J. at 94-98 (cited in note 6) (advancing a similar interpretation of $H B O$ 's ban in light of Vermont Yankee).

${ }^{25}$ As a purely political matter, one may understand the NRC's use of informal rulemaking as a method to cut off burdensome and time consuming debate over nuclear waste issues in its many individual licensing proceedings.

${ }^{28}$ Natural Resources Defense Council v. U.S. Nuclear Regulatory Commission, 547 F.2d 633 (D.C.Cir. 1976).

${ }^{27} 564$ F.2d 458, 474 (D.C.Cir. 1977).

${ }^{28}$ The primary rationale for ACT's request turned on the susceptibility of children to manipulation by television advertising. ACT also called on the FCC to direct television stations to set aside a minimum daily number of hours for children's programming. See id. at 462. 
proposed rules" during the notice and comment period, ${ }^{29}$ broadcasters undertook a series of self-imposed measures to regulate commercials for children. The bulk of these restrictions-covering both the amount and content of such ads-were adopted following a private meeting between broadcasters and FCC officials. ${ }^{30}$ The FCC postponed direct regulation in order "to assess the effectiveness of these self-regulatory measures," adding that "[ $t]$ he standards adopted by the two associations [of broadcasters] are comparable to the standards which we [the FCC] would have considered adopting by rule in the absence of industry reform."31

In upholding the FCC's action, the D.C. Circuit noted:

If we were to accept the proposition implicit in petitioner's [ACT's] argument [against ex parte contacts]-that the FCC may never resort to discussions with members of the industry in a general effort to have its regulatees conform to their public service obligations-the Commission would have little choice but to abandon any reasonable expectation of salutary self-regulation and to affirmatively regulate throughout the areas of children's programming and advertising. ${ }^{32}$

Notably, the $A C T$ court was concerned not with the potential for capture of the agency by regulated industry but, quite the opposite, with the risk that the agency in the future might exercise power over industry through "overbearing 'jawboning' or 'armtwisting' tactics." 33

The facts of $A C T$ exemplify the benefits that can flow from ex parte contacts. Off-the-record discussions represent an important enforcement tool, particularly for agencies concerned with limited regulatory resources. In $A C T$, accomplishment of the FCC's objective-to avoid the burdens of direct regulation in the sensitive area of television content-depended on the willingness of broadcasters to self-regulate. This, in turn, depended on broadcasters' interest in avoiding a potential public defeat in the rulemaking process by assenting to a deal off-the-record whereby broadcasters themselves would adopt similar measures and the FCC would accord them

28 Id. at 463 .

${ }^{30}$ Id. at 464.

31 Id. at 466, quoting Children's Television Report and Policy Statement, 50 F.C.C.2d 1, 13-14; J.A. 1, 18-20 (1974).

${ }^{32}$ ACT, 564 F.2d at 473 n.27.

${ }^{33}$ Id. In the same footnote, the D.C. Circuit referred to an earlier instance where the FCC had used its power over television licenses to "coerce" broadcasters into adoption of a "family viewing hour" rule. 
praise. ${ }^{34}$

Apart from general concerns for limited agency resources, selfregulation frequently will make sense in areas where extensive governmental supervision is undesirable for independent policy reasons. The FCC's report in ACT, for example, noted that the first amendment counsels avoidance of "detailed governmental supervision of programming whenever possible."36 Elsewhere, the Securities and Exchange Commission has a long history of reliance on self-regulatory measures that implement regulatory goals while respecting the autonomy of private financial markets. ${ }^{36}$

Even where the agency does not seek to persuade industry to self-regulate, ex parte negotiations can serve a valuable political function in controversial regulatory areas. With such avenues open, industry has a greater incentive to reveal its willingness to accept particular controls-through self-regulation or otherwise-since it need not run the risk of undermining its outward bargaining position against opposition groups. Analogous incentives can reduce the political constraints on the willingness of pro-regulation groups to disclose their true negotiating positions to the agency. In this manner, agencies may fashion politically acceptable regulations while minimizing the distortions of gamesmanship and posturing in the rulemaking process.

Apart from its facts, $A C T$ remains important for the development of doctrine concerning ex parte contacts. Dicta in $A C T$ questioned the logic behind $H B O$ 's requirement for disclosure of ex parte contacts in the administrative record, noting that such a standard would present judges with the practical impossibility of flushing out "every informational input that may have entered the decisionmaker's deliberative process."37 $A C T$ would confine dis-

s4 The meeting involved in ACT occurred roughly three years before the D.C. Circuit's opinion in $H B O$. The parties thus would have negotiated against the backdrop of Sangamon Valley, upholding the agencies' prerogative to resist disclosure of ex parte contacts in informal rulemaking.

${ }^{35}$ ACT, 564 F.2d at 465, quoting Children's Television Report and Policy Statement, 50 F.C.C.2d at 6; J.A. at 8.

${ }^{36}$ Former SEC commissioner Roberta S. Karmel has written:

I do not believe the SEC has the present capability to effectively regulate the securities industry without the assistance of self-regulatory organizations. Nor do I believe the Commission can garner the political or economic support to do so. When the SEC attempted to develop a relatively crude computer surveillance system to oversee trading in the markets, it became embroiled in controversy. The industry saw such a system as the first step in "Big Brother" oversight of national market system trading.

Roberta S. Karmel, Regulation by Prosecution: The Securities and Exchange Commission vs. Corporate America 114 (1982).

${ }^{37}$ ACT, 564 F.2d at 477. 
closure to Sangamon Valley's familiar category of proceedings involving "competing claims to a valuable privilege." however, took care not to contradict $H B O$ directly, noting that the FCC's negotiations did not present the court with a situation-like that in $H B O$ - where "the substance of the [ex parte] contacts was kept secret" from the reviewing court. ${ }^{39}$

$A C T$ 's criticism of $H B O$ does not render the case a useless precedent. Rather, $H B O$ represents a tentative effort to reconcile the APA with the changes in administrative practice that have transpired since its enactment in 1946. For most of the twentieth century, the dominant mode of agency action consisted of individualized adjudications-a scenario to which the APA imported adversarial procedures along the judicial model. Yet, with the vast expansion of the federal regulatory presence in the $1960 \mathrm{~s}$ and $70 \mathrm{~s}$, agencies shifted to the more streamlined device of generalized, informal rulemaking. ${ }^{40}$ One can understand the use of more expeditious procedures as a natural response to the demands placed on agencies by modern regulatory legislation.

A corresponding shift occurred in the judicial sphere as well. In the early 1970s, the Supreme Court sharply curtailed the instances in which the judiciary would engage in de novo review of agency fact finding. ${ }^{41}$ Instead the Court declared that "the focal point for judicial review should be the administrative record already in existence, not some new record made initially in the reviewing court." 42

In the presence of radically changed circumstances, judges-even those adhering to a philosophy of judicial restraint-must reinterpret the APA in order to remain faithful to its understanding of appropriate constraints on the exercise of power by administrative agencies. ${ }^{43}$ The APA's conception of infor-

38 Id.

39 Id. at 476 .

10 On these developments, see Antonin Scalia, Vermont Yankee: The APA, the D.C. Circuit, and the Supreme Court, 1978 S.Ct.Rev. 345, 375-7. Notably, this shift coincided with explosive growth in the output of administrative agencies. See Federal Register Analysis, Pages Published, 1936-1986, in Regulatory Program of the United States Government, April 1, 1987-March 31, 1988 at 635 (1986)(exhibit 13 indicating dramatic increase in number of pages per year in Federal Register during early 1970s).

41 Compare Overton Park, 401 U.S. at 415 (restricting de novo review to cases where there are inadequate fact finding procedures in the agency's adjudicatory proceeding or where judicial proceedings are brought to enforce certain administrative actions), with Crowell v. Benson, 285 U.S. 22, 64 (1932)(Article III requires de novo review of all "fundamental" or "jurisdictional" facts).

12 Camp v. Pitts, 411 U.S. 138, 142 (1973).

43 As a law professor, Justice Antonin Scalia observed: 
mal rulemaking along legislative lines should not settle the ex parte contacts question where that initial conception was intertwined with the now unfounded assumption that informal rulemaking would play only a minor part in the administrative agenda. Rather, courts may look to another aspect of the APA, reflected by Sangamon Valley: that restrictions on ex parte contacts should operate in adjudication where that procedure supplied the dominant mode of agency action. Arguably, courts should not permit the shift from adjudication to informal rulemaking to relieve agencies from the political constraints that flow from open exchanges of information among interested parties.

Nonetheless, changes in administrative practice also offer an important caveat to these impulses. While changed circumstances might suggest a need to import the trappings of traditional adjudication to informal rulemaking, such action would undermine the rationale for employing informal rulemaking in the first place: namely, to allow the expeditious formulation of policy without the burdens of adjudicatory procedures. This observation underscores the flaw in HBO's effort to apply the APA's ban on ex parte contacts in adjudication to cases of informal rulemaking. At the same time, it offers guarded support for HBO's second and third requirements-for file and record keeping-as less burdensome affirmations of the need to police discretion, whatever procedural rubric the agency may select.

This is not to say that $H B O$ 's record keeping regime properly reconciled APA ideals with contemporary conditions. As $A C T$ noted, $H B O$ 's insistence on review of the "whole record" would require documentation of every "newspaper editorial" or "eveninghour rumination[]" that might have influenced agency decision makers. ${ }^{44}$ More important, $H B O$ left unexamined the extent to which courts are the appropriate institutions to develop and enforce disclosure standards for ex parte contacts. While $H B O$ signalled a reassessment of the APA, the current case law harbors

I do not mean to denigrate the philosophy of judicial restraint and of strict judicial adherence to statutory text . . . . It is a philosophy that I share. One must be realistic, however, about what it achieves, and about how far one wishes to carry it. When the legislative mandate leaves to the agencies (as earlier Supreme Court opinions said the APA did) broad freedom to alter the underlying realities of administrative practice, then strict adherence to the statute will permit a distortion, rather than enforce an observance, of the original legislative compromise.

Scalia, 1978 S.Ct.Rev. at 382 (cited in note 40).

4564 F.2d at 477. 
considerable uncertainty as to where that reassessment will lead. ${ }^{45}$

\section{Congressional Reform Efforts}

Congressional efforts to regulate ex parte contacts have sent mixed signals as well. The APA's prohibition on ex parte contacts in formal agency proceedings stems from the Government in the Sunshine Act of 1976, ratifying the understanding of Sangamon Valley. In its declaration of policy, the 1976 Act stated that "the public is entitled to the fullest practicable information regarding the decisionmaking processes of the Federal Government."'48 $H B O$ relied, in part, on this general language to support its extension of the prohibition to informal rulemaking. ${ }^{47}$ Yet, as $A C T$ noted, such an inference remains tenuous at best where Congress deleted from an earlier draft of the Act language that would have prohibited ex parte contacts in all agency rulemaking.8

While this legislative history casts doubt on the legitimacy of a flat ban, Congressional attitudes toward $H B O$ 's file and record requirements remain ambiguous. The Regulatory Reform Act, proposed in 1981, sought to amend the APA's informal rulemaking provisions to add a requirement that agencies disclose outside "information" bearing on "the benefits, costs, and adverse effects of a proposed rule" in their notice of proposed rulemaking. ${ }^{48}$ The amendment passed the Senate but not the House..$^{50}$ Based on this outcome, one might argue that courts have no business fashioning disclosure rules for ex parte contacts. Since judicial authority over such communications must rest largely on interpretation of APA provisions, Congress' refusal to compel disclosure through the Regulatory Reform Act's revisions to the APA might indicate that the representative branch has reached no resolution of the matter that would warrant judicial enforcement. ${ }^{51}$

4s Though the D.C. Circuit's decision in Sierra Club v. Costle, 657 F.2d 298 (D.C.Cir. 1981), involving ex parte contacts under the Clean Air Act, offers several interesting ideas developed more fully in Section II.C, no court has offered a comprehensive framework to guide agencies and interested parties.

46 U.S.C.A. \& $552 b$ (Historical Note).

47567 F.2d at 56. $H B O$ did acknowledge that the terms of the Act itself did not extend this far. See id. n.125.

48 564 F.2d at 475 n.28.

4 S. 1080, 97th Cong., 1st Sess. § 3(e)(3), in Regulatory Reform Legislation of 1981, Hearings on S. 344 and S. 1080 before the Senate Committee on Governmental Affairs, 97th Cong., 1st Sess. 282, 294 (1981).

${ }^{80}$ See Breyer and Stewart Casebook at 661 n.130.

s1 For a general theory of statutory interpretation along similar lines, see Frank $H$. Easterbrook, Statutes' Domains, 50 U.Chi.L.Rev. 533, 538-9 (1983). 
For two reasons, courts should resist such inferences in this instance. First, the foregoing interpretation of the legislative history would cause sweeping upheaval in current doctrine. The Act's disclosure provisions composed a minor aspect of a general revision of APA § 553 designed, in large part, to codify developments in scope of review doctrine. For instance, the revised $\S 553$ would have required agencies to accompany any final rule with a description of the policy alternatives it considered as well as an explanation of how the rulemaking file supported its factual conclusions. ${ }^{52}$ Under the "hard look" doctrine, which requires that the administrative record reflect a comprehensive evaluation of alternative policy options by administrative agencies, the Supreme Court subsequently endorsed the substance of these requirements. ${ }^{53}$ An interpretation of Congressional action to bar disclosure requirements thus would have to overturn the hard look as well.

Second, other sections of the Regulatory Reform Act sought to codify broad Presidential review powers over rulemaking. ${ }^{54}$ Accounts of Congressional discussions strongly indicate that the eventual rejection of the proposal reflected Congress' desire to safeguard its own oversight prerogatives from Presidential interference, rather than consideration of the merits of disclosure. ${ }^{\mathrm{BS}}$ Like those of the D.C. Circuit, Congressional efforts in this area have left considerable ambiguity. This state of flux carries special significance in light of the additional opportunities for ex parte contacts engendered by recent reforms within the executive branch.

\section{Executive Orders 12,291 and 12,498}

With these two measures, the Reagan Administration asserted Presidential control over informal rulemaking. The two orders possess both substantive and procedural components that accord

${ }^{52} \mathrm{~S} .1080, \S 3(\mathrm{e})(1)(B)$ and (D), reprinted in Regulatory Reform Legislation of 1981 at 292-93 (cited in note 49 ).

ss The Court did so under APA $\S 706(2)$ (A)'s standard of review for "arbitrary [or] capricious" agency decisions rather than $\S 553$ 's procedural requirements for informal rulemaking, probably due to Vermont Yankee's earlier admonition against judicial supplementation of $\S 553$ procedures. See Motor Vehicles Mfrs. Assn. v. State Farm Mut., 463 U.S. 29 (1983).

${ }^{34}$ See S. $1080 \S \S 4$ and 7, in Regulatory Reform Legislation of 1981 at 297-301, 305-307 (cited in note 49).

${ }^{3 s}$ For a concise summary of Congressional action on the Regulatory Reform Act, see Regulatory Reform Bill Stalled in House, 38 Cong.Q.Almanac 523, 527 (1982)(key opposition occurred when House committee heads "argued that the bill would erode statutes within their committees' jurisdiction and would increase the power of the Office of Management and Budget at the expense of Congress"). 
OMB supervisory power over the rulemaking process. Executive Order $12,291^{\text {b8 }}$ requires agencies to prepare "regulatory impact analyses" for submission to the Office of Information and Regulatory Affairs ("OIRA") within OMB to assure that regulatory action is not undertaken unless the potential benefits outweigh the potential costs. Executive Order $12,498^{57}$ establishes a "regulatory planning process" wherein agency heads must submit to OMB a description of "all significant regulatory actions" to be undertaken in the coming year. The order further authorizes OMB to review these descriptions in light of Presidential priorities.

1. Realignment of Institutional Controls. Though the language of Executive Order 12,291 suggests a rigid, cost-benefit analysis, one may best understand the order in institutional rather than economic terms. Most importantly, the order offers a "method of ensuring that regulatory choices-however they are made-reflect the preferences of high-level executive officials."'88 As supporters of the order correctly note, regulation "spends" social resources-through compliance expenditures-in a manner removed from the President's traditional power to establish budgetary priorities, subject to Congressional authorization. ${ }^{59}$ The two orders contain an implicit theory of modern regulation: that overzealous and unconstrained agencies have spent "too much" on regulatory goals ${ }^{60}$ and furthermore that the President, as the elected official responsible for enforcing the mass of federal regulations, ${ }^{61}$ should undertake an executive "hard look" over agency discretion. ${ }^{82}$ Accordingly, the Reagan measures increase the power of agency heads appointed by the President to scrutinize proposed

se 3 C.F.R. 127 (1982).

${ }^{87} 50$ Fed.Reg. 1,036 (1985).

ss Cass R. Sunstein, Cost-Benefit Analysis and the Separation of Powers, 23 Ariz.L.Rev. 1267, 1276 (1981).

89 Christopher C. DeMuth and Douglas H. Ginsburg, White House Review of Agency Rulemaking, 99 Harv.L.Rev. 1075, 1079 (1986).

Bo See DeMuth and Ginsburg, 99 Harv.L.Rev. at 1081. This rationale for vesting coordination powers in OMB stands in contrast to the prescription recently offered by Richard Stewart under the rubric of "reconstitutive" law. In Stewart's view, the problem "is not too much or too little federal regulation, but federal regulation of the wrong sort," Richard B. Stewart, Reconstitutive Law, 46 Md.L.Rev. 86, 89 (1986)-specifically, excessive reliance on centralized "command-and-control" mechanisms rather than techniques that encourage flexibility and innovation by affected groups. See id. at 87, 101, 104-11.

${ }^{61}$ See Youngstown Co. v. Sawyer ("The Steel Seizure Case"), 343 U.S. 579, 702 (1952) (Vinson dissenting).

${ }^{62}$ See Peter L. Strauss and Cass R. Sunstein, The Role of the President and OMB in Informal Rulemaking, 38 Ad.L.Rev. 181, 191 (1986); DeMuth and Ginsburg, 99 Harv.L.Rev. at 1082 (cited in note 59). 
rules in the early stages and thereby avoid "capture" by the policy preferences of their staffs. ${ }^{83}$

From a structural standpoint, the Reagan orders realign the institutions within government that supervise agency discretion. During the 1960s and early 1970s, the courts had assumed primary responsibility for policing the bounds of agency authority. ${ }^{64} \mathrm{By}$ contrast, Executive Orders 12,291 and 12,498 interpose supervision by the executive branch and thereby raise the possibility of a complementary system of adminstrative oversight. The Reagan measures draw on the unique capabilities of the President to coordinate the work of disparate agencies and to increase their accountability. In this manner, the new Executive Orders support both positive and negative elements of the separation of powers.

2. The Problem of Partisan Intervention: The Roots of Current $O M B$ Practices. While the two orders offer the promise of a more coordinated regulatory system, they also increase the potential avenues for ex parte contacts. Though designed to counter the policy biases of rulemaking agencies, Executive Orders 12,291 and 12,498 themselves engender an institutional suspicion of regulation within $\mathrm{OMB}$, the President's watchdog. Congressional hearings indicate that OMB often has served as the focal point for lobbying efforts to block agency rulemaking. ${ }^{65}$

Congress has devoted the bulk of its attention to OMB involvement in rulemaking by the Environmental Protection Agency ${ }^{68}$ Investigations by both Congress and others have identified instances of undocumented $\mathrm{OMB}$ contacts with regulated industries $^{67}$-contacts that, in turn, have resulted in OMB pressure

6s Strauss and Sunstein, 38 Ad.L.Rev, at 187.

64 See Richard B. Stewart, The Reformation of American Administrative Law, 88 Harv.L.Rev. 1669, 1711-90 (1975).

${ }^{\text {es }}$ For a concise summary of $\mathrm{OMB}$ involvement in agency rulemaking, see Office of Management and Budget Influence on Agency Regulations, S.Prt. 99-156, 99th Cong., 2d Sess. (1986) ("OMB Influence").

${ }^{\text {os }}$ For example, recent Congressional documents summarizing OMB involvement in all areas of regulation devote disproportionate attention to the EPA. See OMB Influence at 2231 (cited in note 65); OMB Review of EPA Regulations, Hearing before the Subcommittee on Oversight and Investigations of the House Committee on Energy and Commerce, 99th Cong., 2d Sess. (1986) ("OMB Review of EPA"). For a thorough and highly critical review of the Congressional materials on EPA, see Erik D. Olson, The Quiet Shift of Power: Office of Management \& Budget Supervision of Environmental Protection Agency Rulemaking Under Executive Order 12,291, 4 Va.J.Nat.Res.L. 1 (1984).

${ }^{67}$ See Olson, 4 Va.J.Nat.Res.L. at 70, 73 (cited in note 66) (industry influence on EPA New Source Performance Standards and National Ambient Air Quality Standards, both involving regulation of air pollution). For an example involving the Department of Health and Human Services, see Alan B. Morrison, OMB Interference With Agency Rulemaking: The 
on EPA for reconsideration of its proposed rules. In some instances, OMB has used industry data and policy arguments to urge consideration of factors barred by statute: for example, compliance costs. ${ }^{68}$ Based on this evidence, Congress and outside critics have assailed OMB as a mere "conduit" of unrecorded ex parte information. ${ }^{69}$

Since the early years of the Reagan orders, Congressional leaders, EPA officials, and outsiders called upon OMB to disclose its contacts with outside parties or other agencies. ${ }^{70}$ Although OMB originally proved willing to reveal written communications, it staunchly opposed demands for further disclosure, arguing that:

[a] requirement to "log" or record meetings or phone calls would create a paperwork nightmare and the potential for endless (and pointless) litigation. . . . Presumably, the standards for judicial review of rules would not be directly changed by this requirement, and agencies would continue to provide a rational basis in the record to support the substance of a rulemaking. If so, it would seem that docketing of meetings and phone calls that OMB may have concerning a rule would be irrelevant to the agencies' formulation of a rule or the court's review of a rule. However, if rules could be overturned upon judicial review because this logging requirement was missed, a very chaotic situation could arise. . . . It would certainly lead to a bonanza of new work for administrative lawyers all seeking to discover communications with OMB that were not properly docketed, instead of dealing with the substance of what the rule required. ${ }^{71}$

Wrong Way to Write a Regulation, 99 Harv.L.Rev. 1059, 1067 n.28 (1986) (labelling requirements for aspirin bottles).

68 See, e.g., OMB Influence at 30 (cited in note 65).

"S See EPA's Asbestos Regulations: Report on a Case Study of OMB Interference in Agency Rulemaking, Comm.Prt. 99-V, 99th Cong., 1st Sess. 102-3 (1985); Olson, 4 Va.J.Nat.Res.L. at 35 (cited in note 66).

${ }^{70}$ For general background on these demands, see Memorandum to House Subcommittee on Oversight and Investigations from Representative John D. Dingell (May 6, 1986), in OMB Review of EPA at 4-12 (cited in note 66) (Congressional demands); Letter to A. James Barnes, Deputy Administrator, Environmental Protection Agency, from Robert P. Bedell, Deputy Administrator, Office of Information and Regulatory Affairs (May 30, 1985), in OMB Review of EPA at 217-22 (responding to EPA demands); Olson, 4 Va.J.Nat.Res.L. at 58-62 (cited in note 66) (demands from outsiders).

71 OMB Response to House Questionnaire, OMB Waivers of Regulatory Impact Analysis Requirements (Question 10), in Regulatory Reform Act, Hearings on H.R. 2327 before Subcommittee on Administrative Law and Governmental Relations of the House Judiciary Committee, 98th Cong., 1st Sess. 977-8 (1983) ("Questionnaire") (emphasis in original). Though Question 10 was directed at contacts between $\mathrm{OMB}$ and the rulemaking agencies, 
Recent events, however, suggest that Congressional oversight of OMB behavior has had tangible effects. Through a June 1986 memorandum from OIRA Administrator Wendy Gramm, OMB instituted a new set of disclosure procedures relating to the operation of Executive Orders 12,291 and 12,498 on review of EPA proposals. $^{72}$ In essence, the memo broadened the categories of information that OMB would reveal to the EPA-that is, the rulemaking agency ultimately responsible for generation of the administrative record. A substantial portion of these directives deal with inter-agency communications, the primary means by which OMB relays its views to the rulemaking agencies. While some have criticized these communications, ${ }^{73}$ inter-agency contacts present less of a threat to the rule of law in light of the Supreme Court's unitary vision of the executive branch in Myers $v$. United States, ${ }^{74}$ recognizing broad Presidential authority to influence policy making by the executive agencies.

More important for present purposes, the Gramm memo contains procedures directed at communications with outsiders. While these communications are not identical to ex parte contacts with the rulemaking agency itself, they do not fall neatly into the Myers mold either. ${ }^{25}$ OMB does not simply transmit the views of the President. Instead, it may convey outside information and policy arguments to the agencies, albeit with the implicit sanction of the White House. Given the critical position of $O M B$ in informal rulemaking, such off-the-record inputs can have an even greater impact than if the interested party had contacted the rulemaking agency directly. The Gramm memo governs these "conduit" contacts.

Initially, the memo notes OMB's earlier policy of disclosing only "written materials" received from outsiders. The Gramm memo goes further by setting forth a special set of procedures to govern OMB review of EPA regulations "on a trial basis."76 OMB

OMB cited the same arguments to rebut demands for disclosure of contacts with outsiders. See id. at 986 (Question 6). For evaluation of OMB's arguments, see Section II.A.1.

${ }_{72}$ Memorandum for the Heads of Departments and Agencies Subject to Executive Order Nos. 12291 and 12498 from Wendy L. Gramm, Administrator, Office of Information and Regulatory Affairs, Office of Management and Budget (June 13, 1986), in OMB Review of EPA at 183-86 (cited in note 66).

${ }^{73}$ See Note, OMB Intervention in Agency Rulemaking: The Case for Broadened Record Review, 95 Yale L.J. 1789 (1986).

${ }^{24} 272$ U.S. 52 (1926).

${ }^{76}$ See Note, 95 Yale L.J. at 1800-04 (cited in note 73) (conceiving of OMB as more than a mere Presidential agent).

${ }^{76}$ The Gramm memo offers to apply these special EPA procedures to any other agency 
must (1) "send EPA copies of all written materials concerning EPA rules" received from outsiders, (2) "advise EPA of all oral communications" with outsiders, and (3) "invite EPA to all scheduled meetings" with such persons. Given OMB's longstanding resistance to disclosure, these measures, in all likelihood, represent concessions in the face of mounting Congressional criticism of OMB's role in EPA rulemaking. In fact, the Gramm memo's disclosure procedures closely parallel provisions of a Rule Making Information Act introduced earlier in 1986, by Senate critics of OMB, but not acted upon. ${ }^{77}$

To grasp the full impact of the new OMB-EPA system for generation of the administrative record, one must look to the EPA's own internal procedures. The Gramm memo's provisions granting EPA access to oral contacts and meetings between OMB and outsiders came at a political price. Congressional investigation indicates that the EPA revised its internal procedures for record keeping as a quid pro quo for the Gramm memo's concessions. ${ }^{78}$

First, EPA specified that "significant new factual data or information likely to affect the [EPA's] final decision" must be placed in the public file but deleted an earlier requirement that "argument affecting a rule" also be revealed. Second, the EPA deleted a requirement that decisions not be taken "on the basis of [undisclosed] information or arguments," substituting a command that final EPA decisions be "supported by the public record and the Agency's rationale [be] fully explained in the preamble to the final rule." $" 7 \theta$

In effect, the deal among Congress, OMB, and EPA mandated disclosure of factual information obtained through ex parte contacts but not off-the-record policy arguments concerning the proposed rule. To control the potential distortions that these secret arguments might produce in the agency's decisional process, the 1986 deal reinforced the hard look's command that the administra-

that chooses to use them. The genesis of the Gramm memo's provisions for the EPA lies in a May 30, 1985 letter to EPA Deputy Administrator A. James Barnes from OIRA Deputy Administrator Robert P. Bedell. For a concise summary of its contents, see OMB Influence at 16 (cited in note 65). The document itself is reprinted in OMB Review of EPA at 216-22 (cited in note 66).

${ }^{77}$ See Rule Making Information Act of 1986, S. $2023 \S 2(\mathrm{~b})$, in 132 Cong.Rec. S341 (Jan. 27, 1986)(requiring OMB to provide agencies with a summary of any "written or oral contact," including "an identification of the person with whom such contact was made and a description of the substance of such contact"). The proposal did not emerge from committee.

${ }^{78}$ See OMB Influence at 17 (cited in note 65).

79 Id. at 16-17. 
tive record support the agency's decision.

The foregoing description of OMB practice raises several issues in the development of standards for ex parte contacts. Do the new OMB rules, read in light of the special EPA procedures, draw the appropriate lines? Should courts generalize the special EPA rules to all administrative agencies? What institutional limitations would judicial intervention encounter in this area? To address these questions, one must consider ex parte contacts in light of the principles behind agency decision making.

\section{The Search for Judicial Solutions}

\section{A. The Ideals of Administrative Decision Making}

At the most basic level, judicial review of agency decisions seeks to confine agency discretion to the bounds set by underlying statutory mandates. To this end, $\S 706$ of the APA specifies that "the reviewing court shall decide all relevant questions of law [and] interpret . . . statutory provisions." ${ }^{80}$ In recent years, courts have developed a variety of tools to ensure not only that agencies remain within statutory bounds ${ }^{81}$ but also that action within those boundaries reflects reasoned decision making. ${ }^{82}$ Ex parte contacts implicate both of these concerns.

1. Adherence to Legal Boundaries. This first consideration appears to offer the most compelling case for some type of disclosure requirement. For example, a statute may direct the agency to disregard compliance costs in developing standards for a particular risk; nonetheless, regulated industry-through $\mathrm{OMB}$-might introduce data and policy arguments based on compliance costs in order to quash the proposed rule. Congressional evidence indicates that this scenario describes several instances of OMB review..$^{83}$

The Supreme Court's decision in SEC v. Chenery Corp. established the fundamental principle that administrative action "cannot be upheld unless the grounds upon which the agency acted in exercising its powers were those upon which its action can be sustained." ${ }^{84}$ Where the court cannot ascertain the factors, legally

so 5 U.S.C. \& 706 (1982),

s1 Fidelity to positive law is assured by the APA's right of review for "legal" wrongs. See 5 U.S.C. $\$ 702$.

${ }_{82}$ The APA authorizes judicial review to ensure that agency decisions are not "arbitrary [or] capricious." See 5 U.S.C. $\$ 706(2)$.

${ }^{83}$ See OMB Influence at $30,32-33$ (cited in note 65) (citing EPA National Ambient Air Quality Standards and OSHA ethylene oxide standards).

s4 318 U.S. 80, 95 (1943). 
valid or otherwise, that entered the agency's decision, it has little basis on which to effectuate Chenery's standard. Under such conditions, so it would seem, courts should have access to the inputs of agency decisions. ${ }^{85}$

The problem of impermissible criteria, however, may not surface in so stark a form. Given Chenery's firm declaration on this matter, an agency would be unlikely-indeed, rather foolhardy-to put forth in court an explanation based solely on impermissible variables. Rather, a more likely scenario would involve a decision for which the agency's actual rationale turned on statutorily forbidden factors but where the agency could put forth at least a colorable-perhaps even a persuasive-explanation based on legitimate criteria.

This second situation raises an ambiguity in current doctrine. In Chenery itself, the Securities and Exchange Commission ("SEC") sought to base an administrative order on principles in existing case law. The Court rejected the SEC's reading of precedent and, furthermore, refused to uphold the order on an alternative ground which the agency itself had not articulated: namely, that SEC enforcement powers extended beyond then existing precedent.

Chenery casts new light on OMB's initial policy argument that disclosure "would create a paperwork nightmare and the potential for endless ... litigation."88 In one sense, the case undercuts OMB's pre-1986 position. Judicial intervention triggered by litigation does not merely assure that a given substantive outcome is within legal boundaries, it also enforces the rule of law by stipulating that the agency reach a legally permissible outcome for legally permissible reasons. Accordingly, it may be desirable that interested parties focus their attention not only on a given rule's substance but also on the quality of the agency's decision making process. ${ }^{87}$

On its facts, Chenery left open the question of whether the judiciary must have access to the actual basis of agency decisions in cases where the agency comes up with an independent, permissible rationale. On this matter, OMB's arguments carry greater weight. The ideal of adherence to law encompasses not only exclu-

${ }^{85}$ See Olson, 4 Va.J.Nat.Res.L. at 32-33 (cited in note 66).

${ }^{86}$ See text accompanying note 71 .

87 Before the Gramm memo, OMB did concede that a court might legitimately overturn a rule for procedural inadequacies "inextricably intertwined with the substance of the rule." Questionnaire at 978 (cited in note 71 ). 
sion of invalid criteria in agency decision making but also fulfillment of the agency's substantive statutory mandate-for example, to assure clean air or safe automobiles. Indeed, this observation parallels the positive and negative aspects of the separation of powers. OMB's pre-1986 position evinces an important recognition of the connection between decisional procedures and the ability of the agency to get its job done. An undifferentiated disclosure requirement applicable to all decisional inputs would vastly increase the potential objections that interested parties could use to impede agency action. Just as agencies themselves can diverge from the ideal of neutral expertise, affected parties may undertake obstructive maneuvers to serve narrow interests inconsistent with statutory goals. In this sense, litigation may undermine statutory directives rather than promote their enforcement. Awareness of this possibility buttresses the policy argument for off-the-record negotiation by the agency ex ante. To reach a more subtle resolution of the Chenery ambiguity-one that reconciles the enforcement of statutory directives with the operational imperatives of agencies-courts should look to the values behind more recent doctrines for review of agency decisions.

2. Reasoned Decision Making. The identification and enforcement of legally permissible criteria reflects a traditional conception of courts as enforcers of law. In recent years, federal courts-led by the D.C. Circuit-have gone further to ensure that agencies take a "hard look" at the available policy options in the exercise of their statutory authority. This doctrine requires the agency to engage in a process of data gathering and analysis that examines the impact of various alternative rules on particular interests identified by statute. Upon review, a court will ask (1) whether the record supports the agency's factual premises and, more broadly, (2) whether the explanation offered by the agency is reasonable in light of the options generated in the record, other plausible policy alternatives, and statutory purposes. ${ }^{88}$

Though the ultimate standard of review under the hard look is a deferential one ${ }^{89}$ the process retains considerable substantive force. First, a remand for more thorough consideration by the agency may entail costly and time consuming proceedings, all under the implicit threat of further judicial review. In the end, (1985)

${ }^{88}$ Merrick B. Garland, Deregulation and Judicial Review, 98 Harv.L.Rev. 505, 546-49

${ }^{80}$ See, e.g., Scenic Hudson Preservation Conf. v. FPC, 453 F.2d 463 (2d Cir. 1971) (ultimately upholding agency decision after remand for further proceedings). 
these burdens can lead to "abandonment or modification of the initial project irrespective of the merits."

Second, the Supreme Court on occasion has shown a willingness to constrain changes in regulatory values through scrutiny of the factual underpinnings of the agency's decision. In Motor Vehicles Mfrs. Assn. v. State Farm Mut., the Court invalidated the National Highway Traffic Safety Administration's ("NHTSA") decision to abandon a passive restraint requirement for automobiles. Where the agency disputed the safety benefits of such a rule but had not seriously considered the possibility of requiring non-detachable passive belts or installation of airbags, the Court could not discern a "rational connection between the facts found and the choice made." scrutiny of an agency's technical evaluations can "expose changes in underlying values"-here, the Reagan Administration's policy of deregulation-in the process of ensuring conformity with the governing statute..$^{22}$ In particular, by examining the reasonability of a final agency decision "in light of the facts, alternatives, and statutory purpose, a court can substantially decrease the odds that an agency decision motivated by improper purposes will escape invalidation." "9s

During the 1960s and early 1970s, courts conceived of judicial review as a way to foster a substitute political process within the agency where all affected interests would be represented and considered. ${ }^{94}$ While the hard look does not reject this view entirely, its requirement of reasoned decision making in the implementation of statutory objectives shifts the focus of judicial review. Attention is less on the process of interest representation per se and more on the substantive technical underpinnings of agency reasoning. ${ }^{95}$ The hard look thus offers an important supplement to interest representation goals where the expansion of participatory rights, operating alone, "is unlikely to resolve the fundamental problem of as-

90 Stephen Breyer, Judicial Review of Questions of Law and Policy, 38 Ad.L.Rev. 363, 383 (1986).

${ }^{91} 463$ U.S. at 43, quoting Burlington Truck Lines, Inc. v. United States, 371 U.S. 156, 168 (1962). 211.

${ }^{92}$ Cass R. Sunstein, Deregulation and the Hard-Look Doctrine, 1983 S.Ct.Rev. 177,

2s Garland, 98 Harv.L.Rev. at 557 (cited in note 88).

24 See the interest representation model developed in Stewart, 88 Harv.L.Rev. at 176090 (cited in note 64).

${ }^{93}$ See Garland, 98 Harv.L.Rev. at 586-591 (viewing State Farm as indicative of a shift from the interest representation model to a fidelity model) (cited in note 88 ). 
serted bias in agency choice."98

This shift in the vision of the administrative process carries implications for the scope of judicial review-implications that, in turn, speak to the ambiguity left by Chenery. The hard look builds upon Chenery's requirement that the agency explain the basis of its decision by reference to legally permissible concerns. After State Farm, a reviewing court may not merely compare the agency's stated rationale with the administrative record. Rather, the second step of the hard look-designed to assure reasoned pursuit of statutory objectives-directs the judiciary to assess the technical quality of agency decision making as a means to uncover the influence of unpermitted values. ${ }^{97}$ State Farm solves the ambiguity left by Chenery by positing that a court can prevent the covert infusion of illegitimate considerations not by seeking to examine all matters that could have entered the decision maker's mind but-less intrusively-by scrutinizing the factual underpinnings of the agency's decision.

A reading of Chenery in light of State Farm suggests that while the judiciary need not demand all conceivable inputs to the agency, courts must have access to those elements that bear on the technical premises of agency decisions. To assess the reasonability of the process by which an agency selects a result from its policy data, a court must be able to examine not only the gaps in the record, as in State Farm, but also any information-particularly of factual data barred by statute-that might act as a similar "danger signal" that the desire for a particular substantive outcome had driven the agency's analysis. ${ }^{98}$

One can understand a standard for disclosure of technical inputs as a reflection of the separation of powers. Specifically, such a standard would accommodate the judiciary's province of assuring the reasoned exercise of statutory authority with the particular specialties of other institutions within the regulatory pro-

${ }^{86}$ Stewart, 88 Harv.L.Rev. at 1777 (cited in note 64) (criticizing the interest representation model as indeterminate for this reason).

${ }^{97}$ This second, more searching prong of the hard look undercuts the argument that disclosure of ex parte contacts is unnecessary where agencies must justify their decisions by reference to the administrative record. See, e.g., DeMuth and Ginsburg, 99 Harv.L.Rev. at 1086 (cited in note 59) (since any rule "not anchored in the record will be overturned . . . ex parte contacts are irrelevant as a legal matter").

${ }^{98}$ In its opinion in State Farm, the D.C. Circuit could not "avoid the conclusion that NHTSA's analysis . . . ha[d] been distorted by solicitude for the economically depressed automobile industry-which is not the agency's mandate-at the expense of consideration of traffic safety, which is." State Farm Mut. Auto. Ins. v. Department of Transp., 680 F.2d 206, 240 (D.C.Cir. 1982)(footnote omitted). 
cess-such as agencies-better equipped to undertake comprehensive technical analyses of various policies. To assess whether this interpretation represents a desirable way to think about ex parte contacts, courts should examine the institutional values behind judicial review as well as the institutional limitations on court-initiated solutions.

3. Experimentation By the Coordinate Branches. As a first impulse, a court might consider generalizing the existing disclosure procedures between OMB and EPA-in effect, making such standards applicable to all agencies. Such a decision, however, would encounter substantial barriers in light of Vermont Yankee's admonition against judicial imposition of procedural requirements beyond those recognized in the APA.99 Nonetheless, the Vermont Yankee opinion and subsequent Supreme Court decisions suggest that current law does not foreclose all court-generated solutions to the ex parte contact problem.

Vermont Yankee distinguishes judicial remedies on the basis of their effects on other institutional actors. After Vermont Yan$k e e$, the appropriate remedy for an inadequate administrative record lies not in "prescription of additional procedural devices" but rather in a remand to the agency for further consideration. ${ }^{100} \mathrm{Ver}$ mont Yankee thus protects the ability of agencies to select suitable procedural devices for generation of an adequate record in light of their familiarity with the regulatory context. ${ }^{101}$ Viewed in this manner, Vermont Yankee stands as a strong vindication of agency experimentation in the procedural realm.

A reading of Vermont Yankee that underscores its institutional deference carries special significance after State Farm's endorsement of the hard look, a device not expressly authorized by the APA. Indeed, Supreme Court decisions in the period between Vermont Yankee and State Farm contained vague hints-eventually unrealized-that the hard look might fall for lack of foundation in the APA. ${ }^{102}$ Courts should read Vermont Yankee and State Farm together as delineating spheres of institutional expertise between courts and agencies. While courts under Vermont Yankee may not impose procedural requirements that

935 U.S. 519 (1978). See Section I.B.

${ }^{100}$ Clark Byse, Vermont Yankee and the Evolution of Administrative Procedure: A Somewhat Different View, 91 Harv.L.Rev. 1823, 1827 (1978).

${ }^{101}$ See id., quoting Stephen F. Williams, "Hybrid Rulemaking" Under the Administrative Procedure Act: A Legal and Empirical Analysis, 42 U.Chi.L.Rev. 401, 454-55 (1975).

${ }^{102}$ See Strycker's Bay Neighborhood Council v. Karlen, 444 U.S. 223, 227-28 and n.2 (1980); Note, The Supreme Court, 1982 Term, 97 Harv.L.Rev. 70, 235 (1983). 
supplant experimental prerogatives within the agencies' own sphere, courts may, in line with State Farm, develop general criteria for the adequacy of the administrative record in order to safeguard their institutional prerogative to declare law. The Vermont Yankee-State Farm line prevents courts from using their authority for judicial review "on the record" as a bootstrap to dictate procedural requirements within the agencies beyond those in the APA. State Farm's mandate that the agency generate a range of policy alternatives provides a yardstick for judicial inquiry but does not dictate specific procedures to the agency for accomplishment of this task. For purposes of ex parte contacts, the Vermont YankeeState Farm line thus suggests that while courts may not generalize existing OMB-EPA disclosure rules, they may set forth principles for ascertaining the adequacy of the administrative record. This argument carries added force when the administrative record supplies the sole basis for judicial review. ${ }^{103}$

\section{B. Sources of Law}

1. APA Scope of Review Provisions. The strongest textual source of judicial authority over ex parte contacts lies in APA $\S$ 706's command that courts "shall review the whole record" to determine whether a given agency decision is "arbitrary [or] capricious."104 In $H B O$, the D.C. Circuit interpreted $\S 706$ 's "record" requirement in light of the interest representation goals then thought appropriate to guide judicial review. Under this view, the administrative record was adequate to evaluate a claim of arbitrar-. iness only if it reflected an adversarial discussion among the various interested groups. After State Farm, however, courts should define criteria for the adequacy of the administrative record not by reference to interest representation per se, but as a component of the judicial inquiry needed to ensure a reasoned choice among policy alternatives. Within this latter reading of $\S 706$, a standard for disclosure of technical information and data to facilitate evaluation of agency reasoning is more than a purely procedural directive of the Vermont Yankee variety. Rather, courts should conceive of this standard as a means to fulfill the APA's substantive directive against arbitrary or capricious decisions. In this sense, the hard look's reconceptualization of the "arbitrary [or] capricious" standard as a demand for technical sophistication in the pursuance of 
statutory goals represents a refinement on $H B O$ 's reading of $\S 706$.

2. Constitutional Due Process. A second, more radical and problematic source of judicial authority stems from requirements of due process in economic regulation. Under existing doctrine rooted in Londoner $v$. Denver ${ }^{105}$ and Bi-Metallic Co. v. Colorado, ${ }^{106}$ due process requires a hearing in adjudication but not in rulemaking. In the latter type of proceeding, courts will find due process satisfied where judicial review after-the-fact acts as a substitute for hearings in advance of agency action, by linking coercive agency action to some source of legislative authority. ${ }^{107}$

The justifications for this-distinction once again embody a bipolar conception of the administrative state. ${ }^{108}$ The first justification speaks to accountability. Under this view, political controls exist with respect to rulemaking, usually affecting large segments of the populace, which are present to a far lesser extent in adjudication, where the agency sets policy through resolution of only two parties' claims. As a consequence, adjudication would seem to present a stronger case for surrogate safeguards in the form of participatory rights. Yet, this argument neglects the ambiguous institutional position of administrative agencies. Where agencies enjoy a degree of insulation not possessed by traditional policy making bodies-namely, elected legislatures-political checks may fail to constrain agency decisions even in rulemaking. The imperfect accountability of agencies thus suggests that the argument for surrogate political checks in adjudication does not go far enough.

A second justification suggests that the relevant distinction rests not on sheer political numbers but on the nature of the issues involved. Kenneth Culp Davis, for example, distinguishes "adjudicative facts," particular to the parties and therefore suitable for an individualized hearing, from "legislative facts" in the form of information generally ascertainable by a policy making body. ${ }^{100}$ Yet, Davis' distinction undervalues the potential benefits of discussion in rulemaking. Where agencies must set policy in areas of considerable technical complexity, discussion among interested groups can substantially enhance agency fact finding. In this way, participatory rights can support expertise values.

$H B O$ sought to amend the traditional bipolar view by im-

\footnotetext{
105210 U.S. 373 (1908).

108239 U.S. 441 (1915).

107 See Southern Ry. Co. v. Virginia, 290 U.S. 190, 197 (1933).

108 See Cass, 72 Va.L.Rev. at 367-70 (cited in note 20).

109 Kenneth Culp Davis, I Administrative Law Treatise § 7.02 413-15 (1958).
} 
parting due process considerations to informal rulemaking. There, the D.C. Circuit viewed secret off-the-record communications as subversive of adversarial discussion before the agency and thus inconsistent with "fundamental notions of fairness implicit in due process." $\mathrm{HBO}$ used this argument to support its filing requirement for all forms of ex parte contacts, noting that even if the agency had disclosed these contacts in the record for judicial review, the court still would lack "the benefit of an adversarial discussion among the parties."111 $H B O$ thus rejects the traditional bright line between rulemaking and adjudication for due process purposes.

Recent changes in administrative practice may provide a further foundation for a more expansive reading of due process. Londoner and Bi-Metallic rested on the implicit assumption that agencies would exercise power primarily through adjudicatory proceedings involving formalized hearings. The shift to informal rulemaking as the dominant method of policy making thus offers a plausible ground for courts to transfer the participatory norms of due process to this latter procedure, at least in some form, to remain faithful to Londoner and Bi-Metallic.

Despite the considerable appeal of the expansive view, courts may pursue a less radical reading of due process. Specifically, courts should refine $H B O$ 's view by reference to recent changes in the prevailing understanding of the judiciary in the administrative process. Particularly under the hard look, modern courts can play a far greater role in overseeing agency decision making than they did in the age of Londoner and Bi-Metallic. Today, the dominant concern is not only for a simple correspondence between agency actions and the governing statute, but also for a reasoned choice among all the options that lie within the field of permitted results. Under current doctrine, one need not rely solely on ex ante participatory rights to assure quality decision making by agencies. Rather, where courts direct their attention to the technical underpinnings of agency choice within statutory bounds, judicial review may serve as a surrogate for discussion among the parties at the policy formulation stage when such review encompasses disclosure of all factual inputs. This reasoning offers a latent due process ground for State Farm's broad reading of the APA's "arbitrary [or] capricious" standard and its attendant implication that the administrative record needed to enforce this substantive standard 
must include all factual inputs.

The foregoing modification of HBO's vision possesses three advantages. First, as a doctrinal matter, it remains faithful to the early case law's insight that due process can be satisfied where judicial review-here, based on an adequate record defined in light of State Farm-provides a substitute for participatory rights before the agency. If anything, current conditions suggest that the argument for substitution is even stronger than in the Londoner$B i-M e t a l l i c$ era. The liberalization of standing, ripeness, and exhaustion limitations in recent years means that interested parties need not wait for the initiation of coercive adjudication before seeking review in court.12

A second, related point goes to agency autonomy and the institutional teachings of Vermont Yankee. Constitutionalization of an adversarial process for data collection by the rulemaking agency would rigidify administrative decision making. This concern for flexibility does not stem solely from pragmatic considerations, which alone cannot trump purported constitutional mandates, but instead from competing constitutional values grounded in the separation of powers. The transfer of traditional adjudicatory procedures to informal rulemaking suggested by $H B O$ remains insensitive to the greatly enhanced responsibilities of agencies for the execution of federal public law-a task ultimately rooted in Article II's affirmative command for the President to assure that "the Laws be faithfully executed."113 In the presence of an expanded federal agenda for public policy, courts cannot simply transfer the formal participatory norms fashioned in an era of limited government to the present context without substantially impairing the execution of federal policy. A due process jurisprudence that, instead, conceives of judicial review as a substitute for specified formal procedures can secure quality decision making while maintaining prerogatives for experimentation by agencies in the pursuit of public policy objectives. One may understand this interpretation of due process-like the Reagan Executive Orders-as a reflection of an emerging cooperative system among governmental institutions that remains sensitive to both the positive and negative aspects of the separation of powers.

Third, this revision of due process bears a stronger correspon-

112 On these developments, see Breyer and Stewart. Casebook at 1080-1160 (cited in note 5).

${ }^{123}$ U.S.Const. art. II, $\S 3$. Of course, this argument based on executive power does not extend to independent agencies. 
dence to current understandings of administrative agencies. The primary goal is not facilitation of interest representation, as reflected in HBO's all-encompassing filing requirement conceived to facilitate adversarial dialogue before the agency. Rather, the objective is to assure fidelity to law through scrutiny of agency fact finding, however the agency chooses to accomplish this task. The latter approach suggests a disclosure requirement confined to the placement of all factual inputs in the record for judicial review. ${ }^{114}$

\section{C. "Hard" v. "Soft" Inputs}

The D.C. Circuit's encounter with ex parte contacts in Sierra $C l u b v$. Costle purported merely to interpret provisions of the Clean Air Act governing off-the-record communications.115 The case has proven influential beyond the confines of the Act, however, in formulating a distinction between "hard" data and analysis, which must be placed on the record, and "soft" political arguments, which need not be disclosed. ${ }^{116}$ Notably, EPA's current specification to disclose "data and information" but not "argument" implements a similar approach.

The framework of institutional autonomy developed above offers support for the Sierra Club approach. Pursuant to Chenery and State Farm, courts must be able to ascertain the technical inputs to agency decisions in order to guard against injection of impermissible criteria. The disclosure of "hard" data thus fits within the rubric of measures that define the adequacy of the administrative record without dictating agency procedures to meet this standard. ${ }^{117}$

The exclusion of "soft" political arguments rests on a similar

114 A related argument for a filing requirement rests on APA § 553's stipulation that an agency "shall give interested persons an opportunity to participate in ... [informal] rule making." 5 U.S.C. $\$ 553(c)$ (1982). One might read the word "participate" in itself to imply a policy making process in which all inputs to the agency's decision are subject to scrutiny and rebuttal by other interested parties. This statutory claim is subject to the same three counterarguments that undercut $H B O$ 's broad interpretation of constitutional due process.

115657 F.2d 298 (D.C.Cir. 1981). The relevant provision of the Clean Air Act requires that the public docket file include "all written comments and documentary information on the proposed rule received from any person for inclusion in the docket during the comment period." 42 U.S.C. \& 7607(d)(4)(B)(i) (1982).

${ }^{116}$ See Breyer and Stewart Casebook at 660 (cited in note 5). Despite these broad implications, Sierra Club itself did not purport to govern " 'conduit' communications, in which administration or inter-agency contacts serve as mere conduits for private parties." 675 F.2d. at 405 n.520.

${ }^{117}$ For an example of current protections for "hard" data containing trade secrets, see Ruckelshaus v. Monsanto Co., 467 U.S. 986, 994-97 (1984) (protection for producer's data on environmental effects of its pesticides). 
demarcation of institutional roles. Agency decision making influenced by informal lobbying, in all likelihood, parallels the process that Congress would follow if it formulated the rule itself. ${ }^{118} \mathrm{How}$ ever, one need not rely on assimilation of agencies into the legislative mold to support differentiation of "soft" policy inputs from "hard" data.

Given the awesome responsibility for public welfare that modern American government has placed on administrative agencies, "politics" in the guise of value judgments within delegated authority forms an indispensable element for accomplishment of statutory objectives in the face of often vague statutory mandates. ${ }^{119}$ As the discussion of $A C T$ demonstrates, the capacity of agencies to fashion politically palatable rules and thereby avoid burdensome litigation after the fact often turns on their ability to obtain the true policy preferences of interested parties off-the-record. ${ }^{120}$ While the availability of swift and often intense substantive review makes the courts a plausible substitute for adversarial discussion in the due process area, the potential for judicial review to impose costly delays on agency action increases the desirability of early resolution.

Absent an ability to make informal assessments concerning the risk of outcry from all sides, an agency might plausibly choose inaction $^{121}$ - a decision presumptively unreviewable after Heckler $v$. Chaney. ${ }^{122}$ Under such conditions, disclosure of "soft" political arguments, ostensibly to enhance judicial review, could have the perverse consequence of producing agency decisions that would enjoy heightened protection under current law.

Agency inaction is troublesome for a second reason, apart from considerations of judicial review. On a more subtle level, the inaction engendered by disclosure of political arguments could inhibit developments in the selection of regulatory tools. Current law exhibits considerable reliance on hierarchical "command-and-control" techniques that require federal agencies to collect vast

118 Antonin Scalia, Two Wrongs Make a Right, Regulation 38, 40 (July/Aug. 1977).

110 This insight undercuts the case for an all-encompassing disclosure requirement. The ABA Section of Administrative Law, for example, has recommended that OMB disclose "all substantive communications with persons outside the executive branch" regarding its authority under Executive Orders 12,291 and 12,498. American Bar Association, Administrative Law Section, Recommendation, in 38 Ad.L.Rev. 206, 207 (1986).

${ }^{120}$ See text at notes 9-11; Sierra Club, 657 F.2d at 401; Scalia, Regulation at 41 (cited in note 118).

121 Scalia, Regulation at 41.

122470 U.S. 821 (1985): 
amounts of data and to formulate regulatory standards for a wide range of primary conduct. Air pollution standards represent a paradigmatic example of this approach. ${ }^{123}$ Recently, however, several commentators have noted that the federal government could accomplish these regulatory objectives more efficiently-and with a greater degree of political acceptability-by shifting to less centralized methods that allow those affected by regulation to enjoy greater flexibility: for example, transferable pollution permits that let federal regulators control overall pollution levels while using market mechanisms to establish permitted levels for individual regulatees. ${ }^{124}$ To the extent that an agency chooses inaction, disclosure of political arguments promotes the status quo and consequently encourages reliance on existing "command-and-control" techniques. ${ }^{125}$ The debate over ex parte contacts in informal rulemaking thus has the potential to inhibit such regulatory reforms.

\section{D. "Chilling" Effects and the Institutional Limitations of Courts}

While courts possess legal authority to implement a "hard" data "soft" political arguments standard for the adequacy of the administrative record, courts nonetheless should remain mindful of prudential considerations that counsel against a judicially formulated regime. Disclosure requirements of any sort carry the risk that they will "chill" communication in general, even of desirable "soft" policy arguments. ${ }^{126}$ While estimates of the magnitude and scope of this effect are necessarily speculative absent empirical study of the OMB-EPA measures, one may posit several lines of reasoning on this matter.

One argument says that the "chill" will not impede desirable interchange between the agency and interested groups. Where the underlying statute does not bar consideration of compliance costs, for example, industry will have no reason to feel embarassed when it presents input—either "hard" or "soft"-on the economic burdens of regulation. Indeed, the Supreme Court in recent years has

${ }^{223}$ See Clean Air Act, 42 U.S.C. $\$$ 7401-7642 (1982).

${ }^{24}$ See Richard B. Stewart, Regulation, Innovation, and Administrative Law: A Conceptual Framework, 69 Cal.L.Rev. 1256, 1332-37 (1981). See generally, Stephen Breyer, Regulation and Its Reform (1982).

${ }^{125}$ On the potentially counterproductive effect of continued reliance on "commandand-control" techniques, see Stewart, 46 Md.L.Rev. at 97-102 (cited in note 60).

${ }^{128}$ The danger of a chilling effect might also support the argument that soft data should not be disclosed, since even a limited, Sierra $C l u b$ disclosure regime still might chill communication of desirable soft inputs. 
displayed a receptiveness to the idea that administrative agencies should update the social priorities in regulatory legislation from the 1960 s and 70s-at least where present day concerns for international competitiveness and industrial vitality are not expressly barred by those statutes. ${ }^{127}$

While the general public or other interested parties might mistakenly perceive legitimate industry criticisms of agency policy as attempts at capture, industry lobbyists would remain free to refute such claims. As in the first amendment area, the proper remedy for inaccurate speech is more speech, not silence. ${ }^{128}$ Conversely, the "chilling" effect might operate most strongly and most desirably where an interested party sought to capture the agency-through the infusion of skewed data and statutorily forbidden policy argu-

${ }^{127}$ Industrial Union Dept. v. American Petrol. Inst. ("Benzene"), 448 U.S. 607 (1980), foreshadowed Executive Order 12,291's concern for cost-efficiency in its rejection of OSHA's effort to tighten standards for benzene exposure. The underlying statute directed OSHA to set standards at a level "which [would] most adequately assure[], to the extent feasible, . . . that no employee will suffer material impairment of health." 29 U.S.C. § 655(b)(5) (1982). In construing this language, the Supreme Court rejected OSHA's interpretation that the statute required it "to set an exposure limit at the lowest technologically feasible level that will not impair the viability of the industries regulated." 448 U.S. at 613 . Instead, the Court held that OSHA must make a threshold finding of "significant" risk under current regulations before it could impose the economic burdens of a more stringent standard. 448 U.S. at 639 , 645 .

More recently, the Supreme Court in Chevron U.S.A. v. Natural Res. Def. Council, 467 U.S. 837 (1984), ratified EPA's "bubble" concept designed to reconcile air pollution abatement with industrial expansion. The "bubble" concept referred to the agency's interpretation of the Clean Air Act to permit a plantwide definition of an air pollution "source" that, in turn, would allow industry to add new pollution sources as long as total emissions from a given plant remained the same. The Supreme Court upheld the EPA's reading despite strong evidence, relied on by the D.C. Circuit below, that Congress originally intended "new source review requirements to operate not simply as a quality-maintaining scheme but specifically to promote the cleanup of nonattainment areas [where air pollution from existing sources exceeded national standards]." National Resources Defense Council, Inc. v. Gorsuch, 685 F.2d 718, 720 (D.C.Cir. 1982). In language demarcating a wide territory for interstitial law making by the executive branch, the Court noted:

[A]n agency to which Congress has delegated policymaking responsibilities may, within the limits of that delegation, properly rely upon the incumbent administration's views of wise policy to inform its judgments. While the agencies are not directly accountable to the people, the Chief Executive is, and it is entirely appropriate for this political branch of the Government to make such policy choices-resolving the competing interests which Congress itself either inadvertently did not resolve, or intentionally left to be resolved by the agency charged with the administration of the statute in light of everyday realities.

467 U.S. at 865-66. For criticism of Chevron, see Cass R. Sunstein, Constitutionalism After the New Deal, 101 Harv.L.Rev. 421, 465-69 (1987). Read together, Benzene and Chevron convey an implicit recognition-albeit one limited by statutory terms-of the benefits that can flow from vigorous reassessment of statutory directives.

128 See Whitney v. California, 274 U.S. 357, 377 (1927) (Brandeis concurring). 
ments-to advance its own self-serving ends in a manner hidden from public scrutiny.

Despite these arguments concerning a "chilling" effect, courts should remain aware that the categories of technical information and policy arguments are by no means airtight. Where the justification for permitting secret policy arguments lies largely in convincing interested parties to reveal their true negotiating positions, demands for disclosure of "hard" data could deter such "soft" inputs. The willingness of an interested party to accept a particular level of regulation may be intertwined with a set of data which that party, as a matter of prudent political strategy, chose not to reveal to opponents in the normal notice and comment process. Under such circumstances, even a disclosure regime limited to "hard" inputs would deter the revelation of valuable "soft" preferences necessary for the agency to implement public policy while minimizing litigation after the fact.

The uncertain magnitude and scope of the "chilling" effect underscore a shortcoming of the judiciary as a standard-setting institution in this area. A court faced with ex parte contacts possesses only attenuated powers to gather information that may be crucial to its decision. While amicus opportunities and liberal standards for intervention are helpful in this regard, a court cannot initiate a comprehensive notice and comment procedure to ascertain the potential "chilling" effect of various disclosure rules on all relevant groups.

Apart from informational worries, the doctrine of stare decisis makes judicial solutions difficult to alter in light of subsequent empirical evidence. The rigidification of precedent would operate most strongly if a court were to select a constitutional due process ground for its disclosure regime, for Congress would be left without power to alter the judicially prescribed procedure. The uncertain and potentially paralyzing consequences of the "chill" therefore counsel reliance on experimentation within the agency realm, subject to Congressional ratification, rather than on immediate judicial solutions.

Taken together, these points suggest that while ex parte contacts threaten judicial solicitude for the technical sophistication of agency decisions as a means to assure adherence to law, the judiciary itself cannot meet this challenge entirely, due to the character of judicial decision making. While expertise in the field of statutes and constitutional principles makes the judiciary a leading candidate to articulate the values at stake in administrative oversight, other institutional actors must help to secure such values in 
practice.

\section{The Merits of Congressional Oversight}

Thus far, the discussion has centered on the interaction between judicial review and agency discretion but has neglected a third body within the regulatory system. In light of the institutional barriers to effective judicial enforcement of ex parte contact standards, Congressional oversight stands as a more flexible alternative for control. To this end, the OMB experience raises several startling points.

First, current OMB disclosure rules represent the product of vigorous, perhaps even vengeful, Congressional oversight. ${ }^{129}$ The disclosure rules that emerged from the political dogfight over EPA go far in preserving the integrity of judicial review on the record. Remarkably, the OMB's new standard for disclosure of written and oral communications, combined with EPA procedures for placement of "factual data or information" in the public file, replicates the line between "hard" data and "soft" political arguments developed above. ${ }^{130}$ The Congressional pressures leading to the Gramm disclosure memo thus stand as an important case study demonstrating the manner in which traditional checks and balances-driven largely by institutional jealousies and partisan political motives-can generate doctrinally desirable solutions.

Second, Congressional oversight addresses several of the institutional limitations faced by courts. In particular, such oversight enhances experimentation and innovation. The experience of OMB and EPA under the new regime may come to support generalization of similar rules through Congressional legislation. Alternatively, it may produce a "chilling" effect blinding the two agencies to legitimate political objections. The key point lies in the superior ability of a non-judicial disclosure regime, over time, to sift valuable experiments from problematic ones and thereby accommodate the concerns of all regulatory participants.

The special Congressional attention devoted to ex parte contacts in EPA rulemaking merits consideration for a third reason. The most vociferous efforts to compel disclosure occurred against

129 To obtain a flavor of Congressional antagonism, see Memorandum to House Subcommittee on Oversight and Investigations from Representative John D. Dingell (May 6, 1986), in OMB Review of EPA at 4-12 (cited in note 66).

${ }^{130}$ The due process argument developed in Section II.B.2 would hold that EPA's decision to reveal "data and information" in the public file goes beyond the minimal requirement of disclosure in the record for judicial review. 
the backdrop of environmental statutes designed to serve the interests of a highly diffuse beneficiary class, precisely the kind of group traditionally understood to stand at a disadvantage in the representative process. ${ }^{131}$ In addition, the OMB disclosure rules have the effect of closing off-at least in part-a useful avenue of influence for regulated industry, a group traditionally seen as wielding inordinate power over regulatory decisions.

While the OMB disclosure rules appear to contradict the predictions of public choice theory, an important caveat is in order. In the EPA case, the interests of regulatory beneficiaries were intertwined with the institutional interests of Congress in a turf battle with OMB over the power to supervise the regulatory process. The result thus may reflect the interbranch jealousies envisioned in the notion of checks and balances rather than a new level of concern for diffuse beneficiary groups. Just as a case or controversy is essential to call forth the remedial powers of an Article III court, so too an institutional threat from one of the coordinate branches-as embodied in the two Reagan orders for OMB-represents a critical mechanism to trigger Congressional oversight. ${ }^{132}$

Fourth, the formulation of disclosure rules took place without significant intervention by the D.C. Circuit since Sierra Club in 1981 and without specific directives from the Supreme Court. Though striking, this observation need not support a rigid, laissez faire posture on the part of the judiciary. While one may attack its outcome, $H B O$ represented an important supplement to Congressional pressures by placing agencies on notice that ex parte contacts constituted a serious threat to the rule of law. Furthermore, one can understand the development of OMB standards for ex parte contacts as the natural outgrowth of a general recognition-in large part traceable to the Supreme Court's interventions in Vermont Yankee and State Farm-of the value of experimentation by other institutional actors.

\section{Conclusion}

The treatment of ex parte contacts during implementation of

${ }^{131}$ Three important works in this area are Robert A. Dahl, A Preface to Democratic Theory (1956); George Stigler, The Theory of Economic Regulation, 2 Bell J.Econ. 3 (1971); Mancur Olson, The Logic of Collective Action (1965).

${ }^{132}$ On the institutional incentives of the various branches, see generally Jesse $\mathrm{H}$. Choper, Judicial Review and the National Political Process 260-78 (1980)(arguing that courts should leave final resolution of separation of powers questions to the interplay of the political process between Congress and the executive branch). 
Executive Orders 12,291 and 12,498 offers tentative lessons on the institutional roles of courts, Congress, and the President:

1. Congressional oversight can protect the integrity of judicial review when the incentives for Congress to assert control over executive agencies parallel the interests of courts in assuring an adequate administrative record. While courts historically have intervened to compensate for distortions in the legislative process and thereby assure consideration of all interests affected by regulation, ${ }^{133}$ vigorous Congressional oversight conversely may compensate for the institutional limitations of court-formulated rules. Indeed, this aspect of the ex parte contacts problem undercuts the prevailing wisdom of the 1960s and 70s that courts should act as the dominant policemen of interest representation by administrative agencies.

2. Pursuant to separation of powers principles, courts can safeguard the prerogatives of other institutions to engage in experimentation within the bounds of law. Such judicial efforts-potentially circumscribing interventions by the judiciary itself-can facilitate the pursuance of reforms both in the selection of regulatory tools and in the alignment of the coordinate branches that oversee administrative decisions. Courts may draw on substantial legal authority to govern ex parte contacts; nonetheless, proper regard for institutional flexibility should temper the appeal of such options where much public policy today depends on agencies for its effectuation. While this judicial posture undoubtedly will leave unresolved questions concerning ex parte contacts in some cases, courts should remain aware of the institutional advantages possessed by agency experimentation-guided by Congressional oversight-for formulation of disclosure rules in the face of uncertainty concerning their effect.

3. These lessons together underscore a break from earlier efforts to assimilate administrative agencies into traditional molds of government action. Instead, courts should recognize in forthright terms the ambiguous position of the administrative state and call forth the particular capabilities of the three traditional branches to circumscribe agency discretion. While judicial review remains a critical source of guiding principles in this endeavor, the values articulated by such cases as State Farm require reinforcement by executive and legislative efforts. The colloquy that produced the

${ }^{133}$ See the interest group representation model developed in Stewart, 88 Harv.L.Rev. at 1713-16 (cited in note 64). 
current $\mathrm{OMB}$ disclosure rules-begun by $H B O$ and refined by both Presidential and Congressional understandings-raises the promise of a cooperative framework among the three traditional branches that simultaneously directs and circumscribes the exercise of rulemaking discretion. 